\title{
Arctic Study of Tropospheric Aerosol and Radiation (ASTAR) 2000: Arctic haze case study
}

\author{
By T. YAMANOUCHI ${ }^{1 *}$, R. TREFFEISEN ${ }^{2}$, A. HERBER $^{3}$, M. SHIOBARA $^{1}, \mathrm{~S}_{\text {. YAMAGATA }}^{4}$, \\ K. HARA ${ }^{1}$, K. SATO ${ }^{1}$, M. YABUKI ${ }^{1}$, Y. TOMIKAWA ${ }^{1}$, A. RINKE ${ }^{2}$, R. NEUBER ${ }^{2}$, R. \\ SCHUMACHTER ${ }^{5}$, M. KRIEWS ${ }^{3}$, J. STRÖM ${ }^{6}$, O. SCHREMS ${ }^{3}$ and H. GERNANDT ${ }^{3},{ }^{1}$ National \\ Institute of Polar Research (NIPR), 1-9-10 Kaga, Itabashi-ku, Tokyo 173-8515, Japan; ${ }^{2}$ Alfred Wegener Institute for \\ Polar and Marine Research Potsdam, 14473 Potsdam, Am Telegrafenberg A43, Germany; ${ }^{3}$ Alfred Wegener Institute for \\ Polar and Marine Research (AWI), Am Handelshafen 12, 27570 Bremerhaven, Germany; ${ }^{4}$ Hokkaido University, \\ Graduate School of Engineering, N18, W8, Kita-ku, Sapporo 060-8628, Japan; ${ }^{5}$ Forschungsgesellschaft für \\ Angewandte Naturwissenschaften, Neuenahrerstrasse 20, 53345 Wachtberg, Germany; ${ }^{6}$ Institute for Applied \\ Environmental Research, Stockholm University, Frescativägen 52-54, S 10691 Stockholm, Sweden
}

(Manuscript received 7 January 2004; in final form 11 November 2004)

\begin{abstract}
The ASTAR 2000 (Arctic Study of Tropospheric Aerosol and Radiation) campaign ran from 12 March until 25 April 2000 with extensive flight operations in the vicinity of Svalbard (Norway) from Longyearbyen airport $\left(78.25^{\circ} \mathrm{N}, 15.49^{\circ} \mathrm{E}\right)$. It was a joint Japanese (NIPR Tokyo)-German (AWI Bremerhaven/Potsdam) airborne measurement campaign using AWI aircraft POLAR 4 (Dornier 228-101). Simultaneous ground-based measurements were done at the international research site $\mathrm{Ny}$-Ålesund $\left(78.95^{\circ} \mathrm{N}, 11.93^{\circ} \mathrm{E}\right)$ in Svalbard, at the German Koldewey station, at the Japanese Rabben station and the Scandinavian station at Zeppelin Mountain (475 m above sea level). During the campaign 19 profiles of various aerosol properties were measured. In general, the Arctic spring aerosol in the vicinity of Svalbard had significant temporal and vertical variability.

A strong haze event occurred between 21 and 25 March in which the optical depth from ground-based observation was 0.18 , which was significantly greater than the background value of 0.06 . Airborne measurements on 23 March during this haze event showed a high aerosol layer with an extinction coefficient of $0.03 \mathrm{~km}^{-1}$ or more up to $3 \mathrm{~km}$ and a scattering coefficient from 0.02 in the same altitude range. From the chemical analyses of airborne measurements, sulfate, soot and sea salt particles were dominant, and there was a high mixing ratio of external soot particles in some layers during the haze event, whereas internal mixing of soot in sulfate was noticeable in some layers for the background condition. We argue that the high aerosol loading is due to direct transport from anthropogenic source regions. In this paper we focus on the course of the haze event in detail through analyses of the airborne and ground-based results.
\end{abstract}

\section{Introduction}

Atmospheric aerosols play an important role in global climate change due to their influence on direct and indirect radiative forcing. However, their various influences are not well determined yet, especially in polar regions. Indeed, there are uncertainties about the impact of aerosols on the climate of the 20th century, the present climate and the potential impact on future climate (IPCC, 2001). Moreover, climate studies are partly limited by a lack of knowledge about the geographical and seasonal variations of aerosol properties and composition.

\footnotetext{
${ }^{*}$ Corresponding author.

e-mail: yamanou@pmg.nipr.ac.jp
}

The Arctic is thought to be sensitive to global warming. Walsh and Chapmann (1998) and Serreze et al. (2000) reported a warming of the air temperature near the surface, especially over the Arctic mainland. Thinning of sea ice was observed in the 1990s over a wide area of the Arctic Ocean (Chapman and Walsh, 1993; Rothrock et al., 1999). Arctic conditions, including the chemical composition of aerosol, high surface albedo in spring and long optical path through the atmosphere, are very complex and thus the influence of Arctic aerosols on the Earth's radiation balance still remains an open question. Arctic haze, a visibility-reduction event that occurs during the Arctic spring, is increasingly being studied because of its various possible environmental impacts. Numerous studies were carried out in the 1970s and early 1980s in the Arctic region (Clarke et al., 1984; Radke et al., 1984; 
Schnell, 1984; Heintzenberg, 1989). The highest aerosol concentrations were recorded in the Arctic spring and a strong seasonal variability of the aerosol burden was observed (Shaw, 1982; Bodhaine and Dutton, 1993; Herber et al., 2002; Ström et al., 2003). Information on Arctic aerosol characteristics is still limited due to the scarcity of observations. Moreover, few data sets exist that give a complete picture of the temporal, vertical and horizontal variation of Arctic aerosols and also the characteristics of the aerosols; thus, more data are needed for modelling and radiative transfer calculations.

The aim of the ASTAR 2000 campaign was to produce a valuable dataset on the temporal and vertical aerosol characteristics near Svalbard in the European Arctic. An advantage of the 2-month campaign was that it provided synchronized groundbased and airborne activities for a wide range of aerosol measurement systems. Moreover, long-term aerosol measurements accompanied the campaign. Thus, we obtained data on the optical, chemical and microphysical properties of the aerosol as well as long-term trends. With the data acquired to date and those which continue to come in, it will be possible to derive the required input parameters for models such as the regional climate model HIRHAM (Dethloff et al., 1996) to assess the climatic impact of Arctic aerosol.

\section{Experimental design and instrumentation}

The field campaign operated from 12 March to 25 April 2000 with flight operations from 15 March to 20 April. Aircraft measurements were made using the German research aircraft POLAR 4 (Dornier 228-101) of the AWI (Alfred Wegener Institute for Polar and Marine Research). Longyearbyen airport was the operational base for all flight activities. Details of the flight locations are listed in Table 1. The airborne and ground-based measurement systems at Ny-Ålesund are compiled in Table 2. The ground-based measurements included remote sensing by LIDAR, sun photometer and sky radiometer. Figure 1 shows the overview of the operational area. Due to the project tasks, the flight operation required special flight conditions up to $25000 \mathrm{ft}$ and took place under cloudless conditions (Hoff, 2000).

Whenever the meteorological situation was favourable for the measurements, we obtained aerosol profiles close to the groundbased systems at Ny-Ålesund. This strategy was chosen to allow us to check how well the time-limited flight measurements represented the aerosol loading for the whole day. Furthermore, this allowed us to compile information on aerosol characteristics below the first flight level. In addition, long-term aerosol measurements at the ground sites were used to ensure that the campaign period represented the aerosol loading during the Arctic spring.

The field experiment also offered the opportunity to acquire data for a comparison with satellite data such as SAGE II (Stratospheric Aerosol and Gas Experiment). Measurements by SAGE II in the Arctic are generally limited by ERBS orbital considerations because SAGE II only has measurement above $70^{\circ} \mathrm{N}$ during April and August. Flights on 17 and 19 April were made to compare aircraft data with those from SAGE II. Early results are given in Thomason et al. (2003).

\section{Results and discussion}

\subsection{Ground-based observations}

The first step in analysing the data was to define the different atmospheric conditions occurring with the aid of the sun photometer measurements in Ny-Ålesund. This was useful because the measurement period of the airborne campaign showed variation in the aerosol loading near Svalbard. A background situation is characterized by an aerosol optical depth (AOD) of $\delta_{\text {aer }}(\lambda)<$ 0.06 whereas an Arctic haze event is defined to occur when $\delta_{\text {aer }}(\lambda)>0.1$ at $500 \mathrm{~nm}$ (see Fig. 2). Based on this AOD classification, three Arctic haze events occurred during the campaign: the periods around 23 March, 1 April and 12 April. An unexpected finding is that sometimes the AOD changed very rapidly from day to day. Figure 2 also shows the AOD data, measured from the POLAR 4 at the lowest flight level of $200 \mathrm{ft}$ very close to Ny-Ålesund. During the campaign, the frequency of "Arctic haze" situations observed by sun photometer measurements was $40 \%$. These results are consistent with long-term ground-based sun photometer data from Ny-Ålesund (Herber et al., 2002). On the other hand, the stratospheric AOD is currently $\delta_{\text {strat }}(\lambda)<$ 0.005 at $525 \mathrm{~nm}$ and thus negligible for this discussion (Thomason et al., 2003). The above findings are consistent with the scattering coefficients by the ground-based nephelometer and particle number concentrations by differential mobility particle sizer (DMPS) and optical particle counter (OPC) measurements from Zeppelin Mountain and Rabben Station (Fig. 3). To understand this classification, ground-based chemical analyses were also compared (lower part of Fig. 3).

The largest haze event occurred at the beginning of the campaign between 21 and 25 March 2000. We focus on this period to describe the course of a typical haze event during the campaign. We compare the airborne measurements on $23 \mathrm{March}$, a typical haze case, with those of 26 March, a typical background case. Large increases in the particle light scattering coefficient and particle number concentration occurred at both ground-based sites during the haze days (Fig. 3). The values increased rapidly on 21 March and decreased after 25 March. The mean hourly values during the haze event were more than two to four times higher than those before and about halved after the haze event (see middle part of Fig. 3 for the corresponding mean concentrations). An example of the ground-based impactor analysis is shown in the lower part of Fig. 3 (from Kriews and Schrems, 1998). The mean concentrations of several anthropogenic trace elements (such as $\mathrm{Cu}, \mathrm{Pb}$ and $\mathrm{Ni}$ ) at Rabben station peaked during the haze period. Also, the wind speed at the ground decreased by almost $50 \%$, the main wind direction changed and the air temperature decreased. These changes indicate that the transport path of the air mass reaching the Svalbard area changed at the end of March. 
Table 1. Airborne activities during ASTAR 2000 and related ground-based activities

\begin{tabular}{|c|c|c|c|c|c|c|c|c|c|c|c|c|c|c|c|}
\hline \multirow[b]{3}{*}{$\begin{array}{l}\text { Flight } \\
\text { number }\end{array}$} & \multirow[b]{3}{*}{$\begin{array}{l}\text { Date } \\
\text { in } 2000\end{array}$} & & & & & \multicolumn{10}{|c|}{ Ground-based measurements } \\
\hline & & \multicolumn{4}{|c|}{ Aircraft measurements } & \multicolumn{3}{|c|}{ Koldewey } & \multicolumn{5}{|c|}{ Rabben } & \multicolumn{2}{|c|}{ Zeppelin } \\
\hline & & Location & Systems & $\begin{array}{l}\text { Start time } \\
\text { (hh:mm) }\end{array}$ & $\begin{array}{l}\text { Duration } \\
\text { (hh:mm) }\end{array}$ & ARL & PMR & $\begin{array}{l}\text { Met. } \\
\text { data }^{a}\end{array}$ & MPL & SR & IN & OPC & IM & DMPS & IN \\
\hline 1 & 15 March & Near Ny-Ålesund, $79^{\circ} \mathrm{N} / 8^{\circ} \mathrm{E}$ & $\mathrm{X}$ & 10:07 & 03:39 & $\mathrm{X}$ & $\mathrm{X}^{\mathrm{b}}$ & $\mathrm{X}^{\mathrm{c}}$ & $\mathrm{X}$ & $\mathrm{X}$ & - & - & - & $\mathrm{X}$ & $\mathrm{X}$ \\
\hline 2 & 20 March & Ny-Ålesund, $79^{\circ} \mathrm{N} / 11^{\circ} \mathrm{E}$ & $X^{d}$ & $12: 13$ & $03: 26$ & $\mathrm{X}$ & $\mathrm{X}$ & $X^{c}$ & $\mathrm{X}$ & $\mathrm{X}$ & $\mathrm{X}$ & $\mathrm{X}^{\mathrm{e}}$ & $\mathrm{X}$ & $\mathrm{X}$ & $\mathrm{X}$ \\
\hline 3 & 23 March & $\mathrm{Ny}$-Ålesund, $79^{\circ} \mathrm{N} / 11^{\circ} \mathrm{E}$ & $\mathrm{X}$ & $10: 30$ & 03:01 & $X$ & $\mathrm{X}$ & $X^{c}$ & $\mathrm{X}$ & $X$ & $\mathrm{X}$ & $\mathrm{X}^{\mathrm{e}}$ & $X$ & $\mathrm{X}$ & $\mathrm{X}$ \\
\hline 4 & 24 March & Longyearbyen, $78^{\circ} \mathrm{N} / 12^{\circ} \mathrm{E}$ & $\mathrm{X}$ & 08:40 & 04:41 & $\mathrm{X}$ & $X^{b}$ & $\mathrm{X}$ & $\mathrm{X}$ & $\mathrm{X}$ & $\mathrm{X}$ & $\mathrm{X}^{\mathrm{e}}$ & $\mathrm{X}$ & $\mathrm{X}$ & $\mathrm{X}$ \\
\hline 5 & 25 March & Ny-Ålesund, $78^{\circ} \mathrm{N} / 12^{\circ} \mathrm{E}$ & $X^{f}$ & $07: 43$ & $03: 32$ & $\mathrm{X}$ & $X^{b}$ & $\mathrm{X}$ & $\mathrm{X}$ & $\mathrm{X}$ & $\mathrm{X}$ & $\mathrm{X}^{\mathrm{e}}$ & $\mathrm{X}$ & - & $X$ \\
\hline 6 & 26 March & E of Svalbard, $79^{\circ} \mathrm{N} / 24^{\circ} \mathrm{E}$ & $X^{f, g}$ & 09:29 & $04: 58$ & - & - & $X^{c}$ & - & - & $\mathrm{X}$ & $\mathrm{X}^{\mathrm{e}}$ & $\mathrm{X}$ & $\mathrm{X}$ & $\mathrm{X}$ \\
\hline 7 & $28 \mathrm{March}$ & Ny-Ålesund, $79^{\circ} \mathrm{N} / 24^{\circ} \mathrm{E}$ & $X^{g}$ & $08: 42$ & $04: 21$ & $\mathrm{X}$ & $\mathrm{X}$ & $X^{c}$ & $\mathrm{X}$ & $\mathrm{X}$ & $\mathrm{X}$ & $\mathrm{X}^{\mathrm{e}}$ & $\mathrm{X}$ & $\mathrm{X}$ & $\mathrm{X}$ \\
\hline 8 & 30 March & E of Svalbard, $76^{\circ} \mathrm{N} / 18^{\circ} \mathrm{E}$ & $X^{g}$ & 11.22 & 04:58 & $\mathrm{X}$ & - & $\mathrm{X}$ & $\mathrm{X}$ & $\mathrm{X}$ & $\mathrm{X}$ & $\mathrm{X}^{\mathrm{e}}$ & $\mathrm{X}$ & $\mathrm{X}$ & $\mathrm{X}$ \\
\hline 9 & 1 April & Longyearbyen, $79^{\circ} \mathrm{N} / 15^{\circ} \mathrm{E}$ & $X^{g}$ & 09:07 & $03: 33$ & $\mathrm{X}$ & $\mathrm{X}$ & $\mathrm{X}$ & $\mathrm{X}$ & $\mathrm{X}$ & $\mathrm{X}$ & $\mathrm{X}^{\mathrm{e}}$ & $\mathrm{X}$ & $\mathrm{X}$ & $\mathrm{X}$ \\
\hline 10 & 2 April & $\mathrm{S}$ of Svalbard, $77^{\circ} \mathrm{N} / 13^{\circ} \mathrm{E}$ & $X^{g}$ & $12: 27$ & $03: 43$ & $\mathrm{X}$ & - & $X^{c}$ & $\mathrm{X}$ & $\mathrm{X}$ & $\mathrm{X}$ & $\mathrm{X}^{\mathrm{e}}$ & $\mathrm{X}$ & $X$ & $\mathrm{X}$ \\
\hline 11 & 4 April & $\mathrm{SE}$ of Svalbard, $76^{\circ} \mathrm{N} / 20^{\circ} \mathrm{E}$ & $\mathrm{X}$ & $13: 02$ & 04:07 & - & - & $X^{c}$ & - & - & $\mathrm{X}$ & $\mathrm{X}^{\mathrm{h}}$ & $\mathrm{X}$ & $\mathrm{X}$ & $\mathrm{X}$ \\
\hline 12 & 7 April & Longyearbyen, $79^{\circ} \mathrm{N} / 15^{\circ} \mathrm{E}$ & $\mathrm{X}$ & 13.13 & $04: 32$ & $\mathrm{X}$ & - & $\mathrm{X}$ & $\mathrm{X}$ & $\mathrm{X}$ & $\mathrm{X}$ & $\mathrm{X}^{\mathrm{h}}$ & $\mathrm{X}$ & $\mathrm{X}$ & $\mathrm{X}$ \\
\hline 13 & 12 April & Ny-Ålesund, $79^{\circ} \mathrm{N} / 12^{\circ} \mathrm{E}$ & $\mathrm{X}$ & $14: 15$ & $03: 28$ & $\mathrm{X}$ & $\mathrm{X}$ & $\mathrm{X}^{\mathrm{c}}$ & $\mathrm{X}$ & $\mathrm{X}$ & $\mathrm{X}$ & $\mathrm{X}^{\mathrm{h}}$ & $\mathrm{X}$ & $\mathrm{X}$ & $\mathrm{X}$ \\
\hline 14 & 13 April & Near Ny-Ålesund, $79^{\circ} \mathrm{N} / 11^{\circ} \mathrm{E}$ & $\mathrm{X}$ & $14: 26$ & 04:56 & $\mathrm{X}$ & $\mathrm{X}$ & $\mathrm{X}$ & $\mathrm{X}$ & $\mathrm{X}$ & $\mathrm{X}$ & $\mathrm{X}^{\mathrm{h}}$ & $\mathrm{X}$ & $\mathrm{X}$ & $\mathrm{X}$ \\
\hline 15 & 14 April & Longyearbyen, $78^{\circ} \mathrm{N} / 15^{\circ} \mathrm{E}$ & $\mathrm{X}$ & $14: 29$ & 04:59 & $\mathrm{X}$ & - & $\mathrm{X}$ & $\mathrm{X}$ & $\mathrm{X}$ & $\mathrm{X}$ & $\mathrm{X}^{\mathrm{h}}$ & $\mathrm{X}$ & $\mathrm{X}$ & $\mathrm{X}$ \\
\hline 16 & 16 April & Ny-Ålesund, $79^{\circ} \mathrm{N} / 11^{\circ} \mathrm{E}$ & $\mathrm{X}$ & $14: 55$ & 03:26 & $\mathrm{X}$ & - & $\mathrm{X}$ & $\mathrm{X}$ & $\mathrm{X}$ & $\mathrm{X}$ & $\mathrm{X}^{\mathrm{h}}$ & $\mathrm{X}$ & $\mathrm{X}$ & $\mathrm{X}$ \\
\hline 17 & 17 April & $\mathrm{S}$ of Svalbard, $74^{\circ} \mathrm{N} / 11^{\circ} \mathrm{E}$ & $\mathrm{X}$ & $15: 50$ & 04:49 & $\mathrm{X}$ & - & $X^{c}$ & $\mathrm{X}$ & $\mathrm{X}$ & $\mathrm{X}$ & $\mathrm{X}^{\mathrm{h}}$ & $\mathrm{X}$ & $\mathrm{X}$ & $\mathrm{X}$ \\
\hline 18 & 19 April & $\mathrm{S}$ of Svalbard, $74^{\circ} \mathrm{N} / 8^{\circ} \mathrm{E}$ & $\mathrm{X}$ & $16: 34$ & $04: 37$ & $\mathrm{X}$ & $\mathrm{X}$ & $X^{c}$ & $\mathrm{X}$ & $\mathrm{X}$ & $\mathrm{X}$ & $\mathrm{X}^{\mathrm{h}}$ & $\mathrm{X}$ & $\mathrm{X}$ & $\mathrm{X}$ \\
\hline 19 & 20 April $^{\mathrm{i}}$ & $\mathrm{Ny}$-Ålesund, $79^{\circ} \mathrm{N} / 12^{\circ} \mathrm{E}$ & $X^{f}$ & 11:02 & $03: 24$ & $\mathrm{X}$ & $\mathrm{X}$ & $X^{c}$ & $\mathrm{X}$ & $\mathrm{X}$ & $\mathrm{X}$ & $\mathrm{X}^{\mathrm{h}}$ & $\mathrm{X}$ & $\mathrm{X}$ & $\mathrm{X}$ \\
\hline
\end{tabular}

Abbreviations: ARL, aerosol Raman LIDAR; PMR, photometer; MPL, micropulse LIDAR; SR, sky radiometer; IN, integrating nephelometer; IM, two-stage impactor; OPC, optical particle counter; DMPS, differential mobility particle sizer.

$\mathrm{X}$ (in systems) = all instruments working (photometer, integrating nephelometer, particle soot/absorption photometer, optical particle counter, impactor, filter sampling and meteorology.

${ }^{\mathrm{a}}$ Radio sounding and BRSN (baseline surface radiation network).

${ }^{\mathrm{b}}$ Also star photometer.

${ }^{\mathrm{c}}$ Additional ozone sounding.

${ }^{\mathrm{d}}$ Only impactor data are available.

${ }^{\mathrm{e}}$ MetOne OPC.

${ }^{\mathrm{f}}$ Without filter sampling.

${ }^{\mathrm{g}} \mathrm{No}$ impactor measurements.

h RION OPC.

${ }^{\mathrm{i}}$ Curtain flight performed.

\subsection{Atmospheric circulation fields and trajectories}

As large-scale meteorological transport systems may have considerable influence on aerosol loading, we analysed the overall meteorological situation during the haze period. The major synoptic pressure system showed an intrusion of Atlantic air masses into the Arctic around 17 to 19 March. That can be seen in the synoptic chart of the $500 \mathrm{hPa}$ height field (Fig. 4). Thus, this northeastward flowing surge of air was likely responsible for the low aerosol concentration at Svalbard around 20 March. On 22 March, a distinctive low-pressure system southeast of Svalbard was established with a primarily northeasterly wind flow pattern. This pressure system remained stable and persistent until 24 March. During the time of the highest aerosol loading, the low moved and expanded southeast. On 25 March, the Svalbard area became more influenced by air masses coming from the northwest. By 26 March the area was dominated by northwesterly flows.

Furthermore, three-dimensional (3-D) backward trajectory analysis was done to examine the origin of the air parcels (Fig. 5). For the trajectory calculation, we used the 3-D winds from ECMWF operational analysis data with a horizontal grid spacing of $2.5^{\circ}$. A linear interpolation method was used for latitudes and longitudes. The vertical interpolation was also made linearly in the log-pressure coordinate. The backward time integration was made over $5 \mathrm{~d}$ with a fourth-order Runge-Kutta scheme. The time step was $1 \mathrm{~h}$, which should be sufficiently small because a time step of 30 min gave about the same results. A cubic spline method was used for time interpolation. All calculations used a starting time of noon. 
Table 2. Observation systems during ASTAR 2000 campaign

\begin{tabular}{|c|c|c|}
\hline System & Measurement & References \\
\hline \multicolumn{3}{|l|}{$\begin{array}{l}\text { Ground-based measurements } \\
\text { Koldewey }\end{array}$} \\
\hline Sun and star photometer & Aerosol optical depth, phase function, refractive index & $\begin{array}{l}\text { Weller et al. (1998), } \\
\text { Herber et al. (2002) }\end{array}$ \\
\hline Aerosol Raman LIDAR & $\begin{array}{l}\text { Aerosol backscattering extinction coefficient and } \\
\text { depolarization factor at } 532 \text { and } 1064 \mathrm{~nm}\end{array}$ & $\begin{array}{l}\text { Ansmann et al. (1990), } \\
\text { Schumacher et al. (2000) }\end{array}$ \\
\hline Meteorology & Temperature, relative humidity, wind speed, wind direction & \\
\hline \multicolumn{3}{|l|}{ Rabben } \\
\hline Nephelometer TSI model 3563 & Scattering coefficient at 3 wavelengths $(450,550,700 \mathrm{~nm})$ & Anderson et al. (1996) \\
\hline Optical particle counter & Particle number concentration & \\
\hline (MetOne model 227B and & MetOne 227B: $D=0.3 \mu \mathrm{m}$ and one of $0.5,1.0,3.0,5.0 \mu \mathrm{m}$ & \\
\hline RION Co. KC-01C & RION KC-01C: $D=0.3,0.5,1.0,2.0,5.0 \mu \mathrm{m}$ & \\
\hline Micropulse LIDAR & Backscatter ratio at $523 \mathrm{~nm}$ & Spinhirne (1993); Shiobara (2000) \\
\hline Sky scanning radiometer & Aerosol optical depth, size distribution, refractive index & Nakajima et al. (1996) \\
\hline 2-stage impactor & $\begin{array}{l}\text { High-volume sampler with a single-stage impactor } \\
\text { (cut-off diameter } 2 \mu \mathrm{m} \text { ): chemical aerosol composition in } \\
\text { dry and wet periods }\end{array}$ & $\begin{array}{l}\text { Kriews and Schrems (1998) } \\
\text { Luedke et al. (1999) }\end{array}$ \\
\hline \multicolumn{3}{|l|}{ Zeppelin Mountain (475 m asl) } \\
\hline Nephelometer TSI 3563 & Scattering coefficient at $450,550,700 \mathrm{~nm}$ & $\begin{array}{l}\text { Anderson et al. (1996) } \\
\text { Ström et al. (2003) }\end{array}$ \\
\hline DMPS & $\begin{array}{l}\text { Particle number concentration. Size range } \\
\text { between } 0.025 \text { and } 0.5 \mu \mathrm{m}\end{array}$ & $\begin{array}{l}\text { Knutson and Whitby (1975) } \\
\text { Jokinen and Mäkelä (1997) }\end{array}$ \\
\hline \multicolumn{3}{|l|}{ Aircraft measurements } \\
\hline Sun photometer & Aerosol optical depth, phase function, refractive index & Nagel et al. (1998) \\
\hline Nephelometer M903 Radiance Res. & Scattering coefficient at $530 \mathrm{~nm}$ & \\
\hline Optical particle counter & Particle number concentration & \\
\hline MetOne model $237 \mathrm{H} \& 237 \mathrm{~B}$ & $\begin{array}{l}\text { Size range } 237 \mathrm{H}: D=0.1,0.2,0.3,0.5,1 \mu \mathrm{m} \\
\text { Size range } 237 \mathrm{~B}: D=0.3,0.5,1,5 \mu \mathrm{m}\end{array}$ & \\
\hline $\begin{array}{l}\text { Particle soot absorption } \\
\text { photometer (Radiance Res.) }\end{array}$ & Absorption coefficient at $565 \mathrm{~nm}$ & Bond et al. (1999) \\
\hline Filter sampling & Ionic and metal constituents & \\
\hline 1-stage aerosol impactor & $\begin{array}{l}\text { Individual particle analysis, mixing state and morphology } \\
\text { observation. Cut-off diameter } \approx 0.2 \mu \mathrm{m} \text { at ground level }\end{array}$ & Hara et al. $(2002,2003)$ \\
\hline Basic sensor systems & Meteorological data & \\
\hline \multicolumn{3}{|l|}{ Satellite } \\
\hline $\begin{array}{l}\text { SAGE II Stratospheric Aerosol and } \\
\text { Gas Experiment II }\end{array}$ & Aerosol extinction coefficient & $\begin{array}{l}\text { Wang et al. (1999), } \\
\text { Thomason et al. (2003) }\end{array}$ \\
\hline
\end{tabular}

For 20 March (upper left in Fig. 5), the backward trajectories show intrusion of a warm air mass from the Atlantic Ocean. Three days later, on 23 March, the backward trajectories show that the air masses in the operation area came from central Siberia and the northern part of Europe and were thus affected by anthropogenic pollution released there (Iversen and Joranger, 1985; Raatz, 1991). The 3-D transport model calculations by Engardt and Holmén (1999) also show that anthropogenic pollution from Siberia can affect the aerosol loadings measured at Ny-Ålesund. According to the trajectory analysis, the aerosol loading on 26 March (upper right in Fig. 5) was not directly affected by mid-latitude emissions. The airflow came from the northwest, which agrees with the overall meteorological situation mentioned above. Therefore, we conclude that the various different aerosol properties and characteristics measured before, during and after the haze period are due to changes in the largescale air mass. The influence of changes in the meteorological circulation pattern on the measurement results is clearly seen in Fig. 3, in agreement with the trajectory climatology reported by Eneroth et al. (2003).

\subsection{Vertical profiles from the surface}

The parallel run of the curves for the scattering coefficient, and the particle number concentration at Rabben and Zeppelin in 
Fig 1. Area of operation of the aircraft measurements during the ASTAR 2000 campaign. All places of measurement are marked. The maximum operational radius for the aircraft measurements was $500 \mathrm{~km}$ from Longyearbyen airport and the maximum measurement time was $5 \mathrm{~h}$. The lowest flight level for the atmospheric measurements were around $0.5 \mathrm{~km}$ and the aircraft climbed up in $1 \mathrm{~km}$ intervals to the highest flight level (approximately $7.5 \mathrm{~km}$ ). The flight speed during measurement was $230 \mathrm{~km} \mathrm{~h}^{-1}$ and the length of a flight leg was $20 \mathrm{~km}$. The average duration of a research flight was $3.5 \mathrm{~h}$. The total research flight time during the campaign was $74 \mathrm{~h}$. The two aircraft measurements described in detail are highlighted.

Fig 2. Classification of aerosol concentration, based on aerosol optical depth measurements with the sun photometer at the ground in Ny-Ålesund and on board Polar 4 at the lowest flight level.
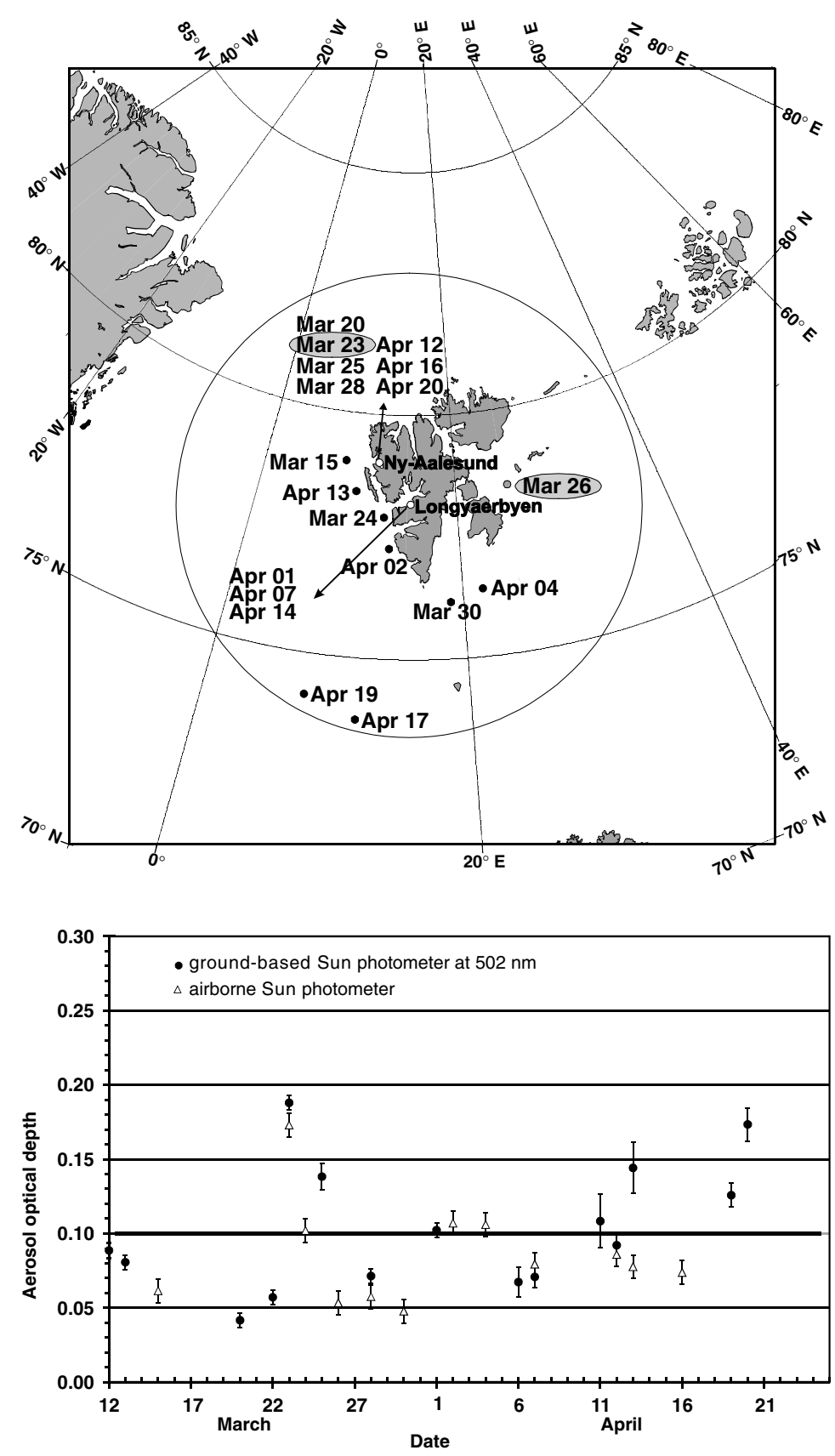

Fig. 3, indicates an aerosol layer at the surface. The soundings in Fig. 5 are consistent with such a layer because they show a stable atmospheric layer during the haze period. For $23 \mathrm{March}$, the first $2 \mathrm{~km}$ were characterized by low wind speeds of mean value $3.3 \mathrm{~m} \mathrm{~s}^{-1}$. The relative humidity is roughly uniform at about $47 \%$ up to a height of $4 \mathrm{~km}$, which indicates a thick well-mixed layer. In contrast, the relative humidity on 20 March is high in the boundary layer and very low above $2 \mathrm{~km}$ (Fig. 5). On 26 March, both the mean relative humidity $(73 \%)$ and the wind speed $(7.9 \mathrm{~m}$ $\mathrm{s}^{-1}$ ) up to a height of $4 \mathrm{~km}$ were much higher than that during the haze event. The aerosol layer during the haze period appeared to travel in dry air masses. The wind direction on 23 March was northeasterly, which was already shown in the large-scale meteorological air flow pattern as well as the trajectory paths.

The aerosol extinction coefficient at $532 \mathrm{~nm}$ based on LIDAR measurements (Table 2) supports these findings. Figure 6 shows the layer thickness, the aerosol layer stability for $2 \mathrm{~d}$, and a breakdown in the middle of 25 March. A stable aerosol layer up to a height of about $4 \mathrm{~km}$ occurred during the haze event, which corresponds with the weather analysis. 


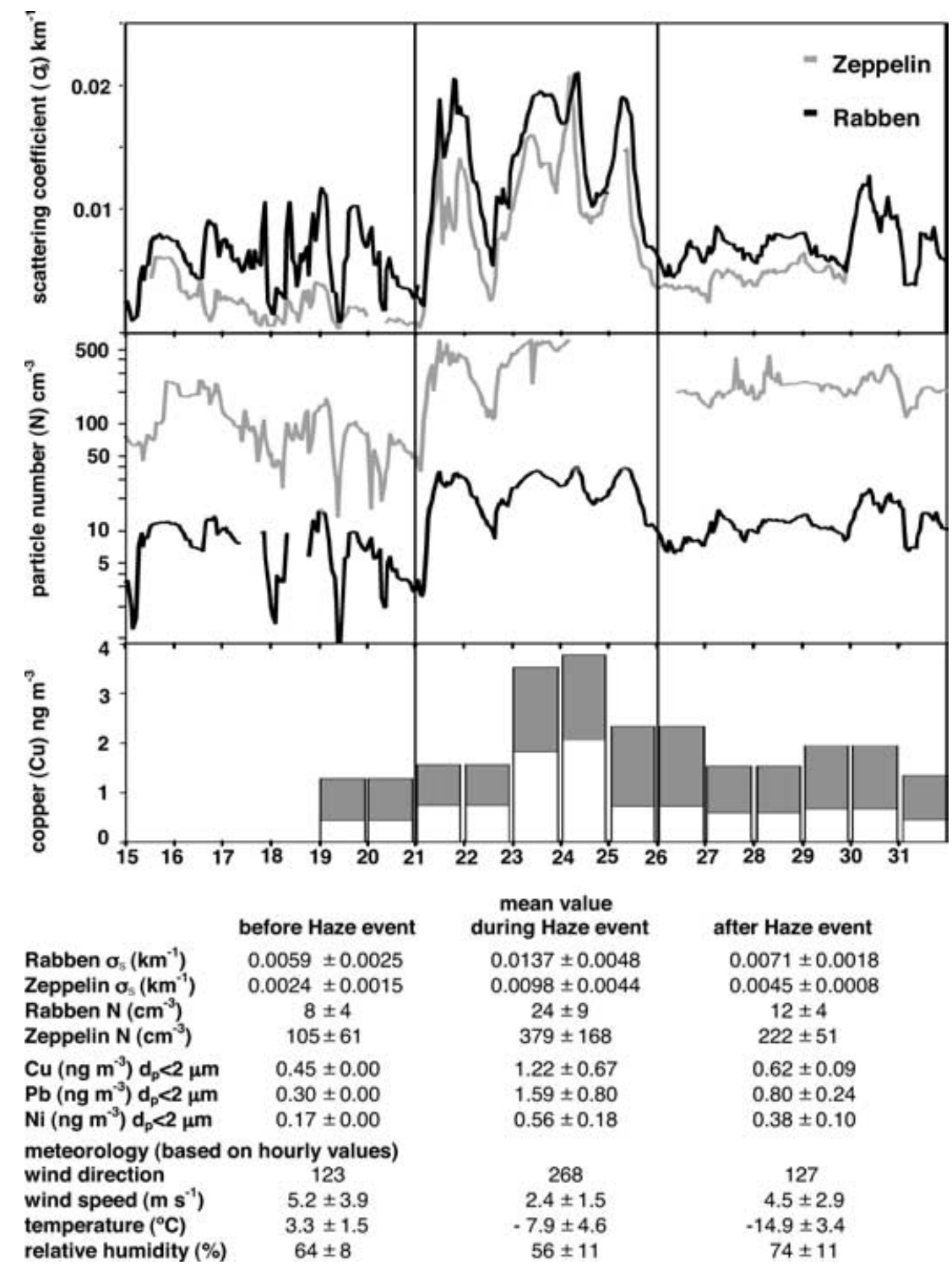

Fig 3. Time series for different ground-based measurements from 15 to 31 March. From top to bottom: nephelometer at Rabben and Zeppelin Mountain, Rion OPC at Rabben (particles exceeding $0.3 \mu \mathrm{m}$ in diameter) and DMPS at Zeppelin Mountain (particles exceeding $0.022 \mu \mathrm{m}$ in diameter), both of which are mean hourly concentrations, and one example for the filter analysis of the two-stage impactor at Rabben. The filter was always changed at 7 p.m. The table at the bottom lists mean values for the ground-based measurements from the values plotted above and from other meteorological measurements. They are divided into before, during and after the haze event.
The ground-based sun photometer measurements (Table 2), which provided column information on the aerosol loading, show an AOD of about 0.18 on 23 March and then an AOD of 0.13 until 10:00 on 25 March. Then, a significant change occurred in the aerosol loading of the atmosphere during 25 March (Fig. 6). The aerosol optical depth at $532 \mathrm{~nm}$ decreased from around 0.12 in the morning to 0.05 in the late afternoon. This decrease must be due to a change in the air mass. Early on 25 March, the air at various pressure levels came from northern Europe and the air masses were therefore characterized by midlatitude emissions (not depicted). Later in the day, the air masses in the observation area came from the northwest (not shown). In summary, the combination of various measurements in the campaign provided a consistent picture of the aerosol conditions and sources.

\subsection{Vertical profile from airborne observations}

The ASTAR campaign provided the opportunity to make simultaneous aircraft measurements for $19 \mathrm{~d}$ (see Table 1). From the discussion of the ground-based measurements above, we concluded that the flight activities during the course of the haze event represented the aerosol loading of the day under consideration. The aircraft observations gave the vertical structure of aerosol extinction, absorption, scattering coefficients and particle number concentrations, independently, as well as the heightdependent chemical composition from impactor measurements from approximately $60 \mathrm{~m}$ above sea level (asl) up to a height of approximately $7500 \mathrm{~m}$ asl.

We now discuss the flight measurements of the vertical aerosol characteristics during and after the haze event on 23 and 26 

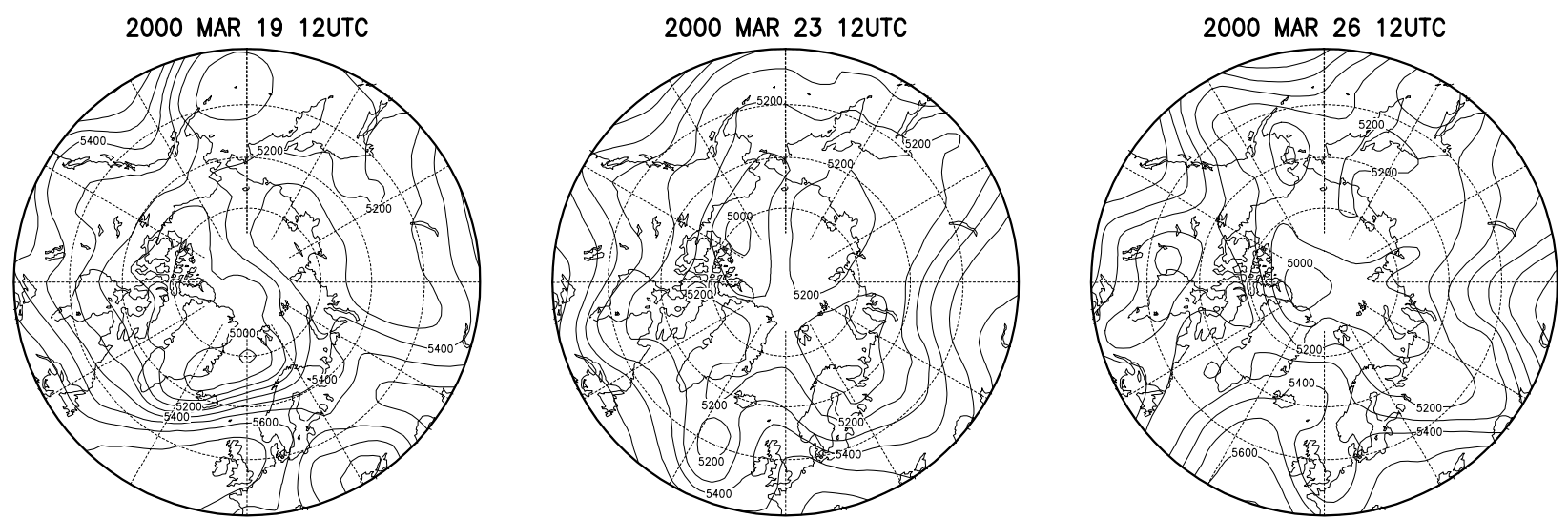

Fig 4. Geopotential height field of $500 \mathrm{hPa}$ for 19, 23 and 26 March from ECMWF operational analysis data.
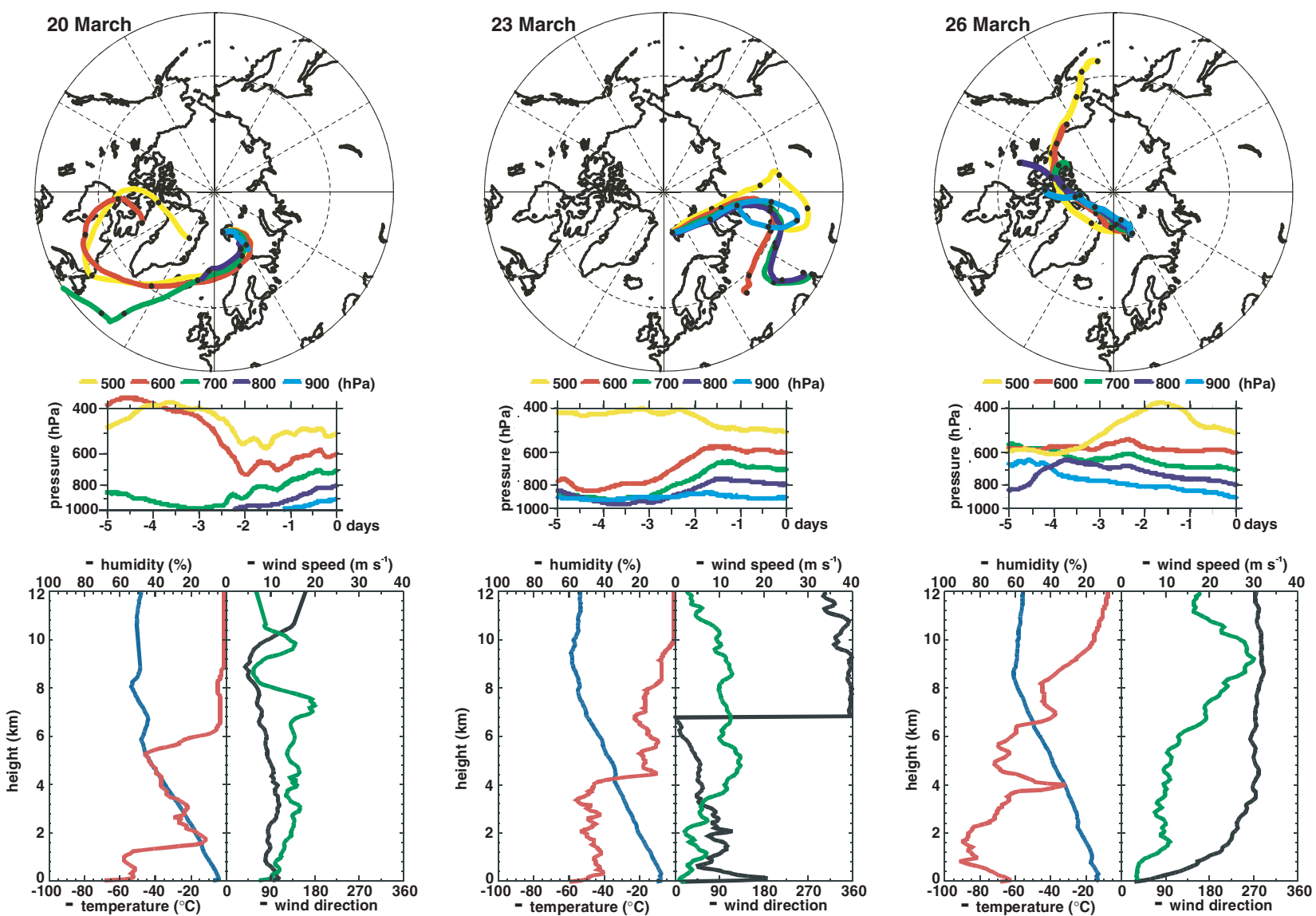

Fig 5. Air mass characteristics for three days. Top: $5 \mathrm{~d}$ backward trajectories started at 12:00 UTC, calculated from ECMWF operational analysis data. Bottom: soundings at 11 a.m. for 20 March (left), 23 March (middle) and 26 March (right).

March (see Fig. 7). The sun photometer measured the optical depth for the column of air above the plane at seven or eight levels. Differences in the optical depths at adjacent levels determine the layer extinction. The in situ aerosol measurements by the OPC, nephelometer and particle/soot absorption photometer (PSAP) were made for the sampled air introduced into a diffuser before being distributed to each instrument (Table 2). The extinction coefficients at 532 $\mathrm{nm}$ from the sun photometer measurements are in good agreement with those derived from in situ measurements (scattering coefficient by nephelometer plus absorption coefficient by PSAP). 

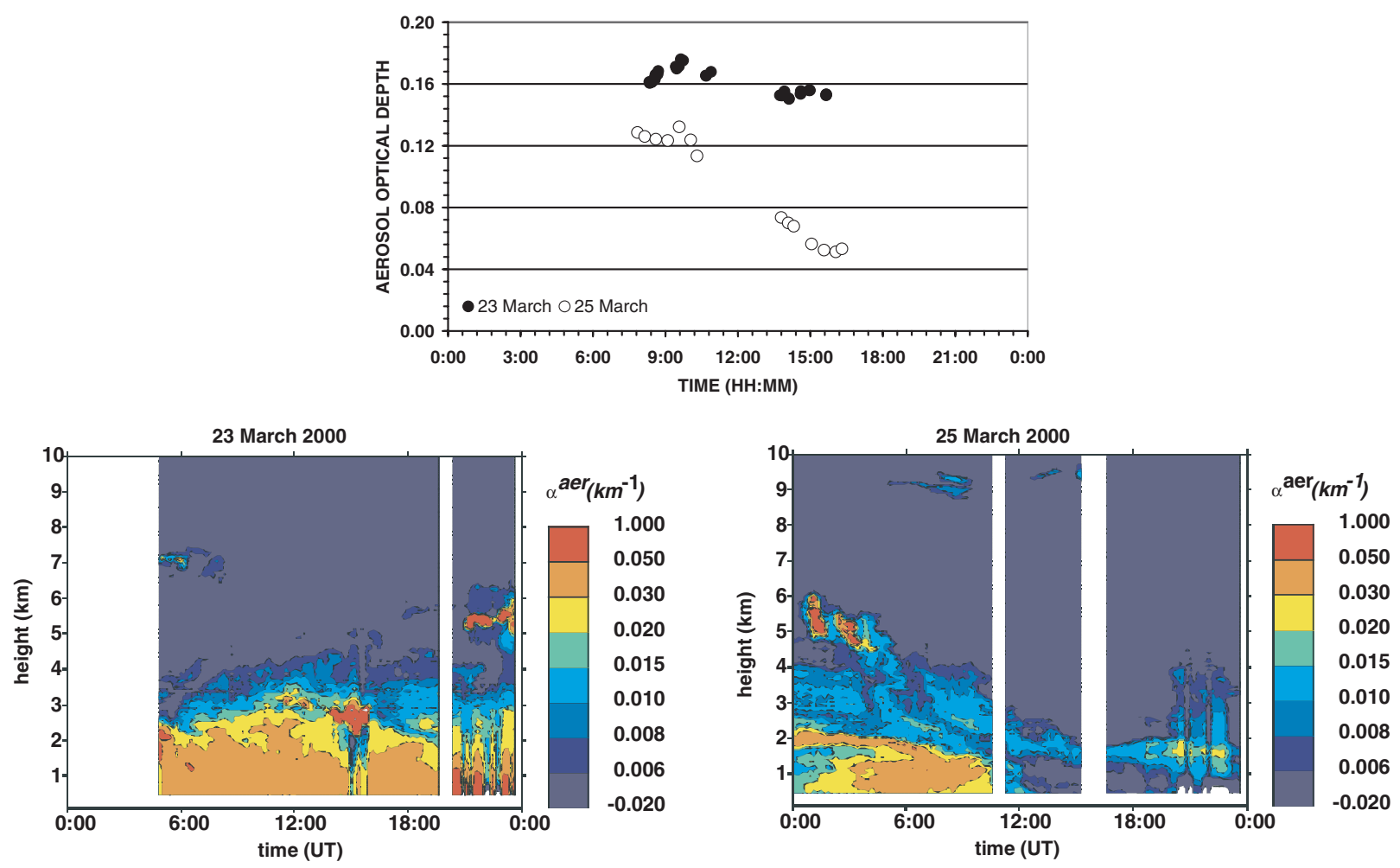

Fig 6. Aerosol optical properties on 23 and 25 March. Top: aerosol particle optical depth. Bottom: the height-time cross-section of the aerosol extinction coefficient at $532 \mathrm{~nm}$ as a function of time from LIDAR measurements.

For both days, a substantial aerosol layer occurred in the lowest $3 \mathrm{~km}$, although the measured extinction coefficients on 26 March were around $60 \%$ less than those on 23 March (Fig. 7 top). On 23 March, the extinction coefficient is about $0.04 \mathrm{~km}^{-1}$ in the $2 \mathrm{~km}$ layer and $0.03 \mathrm{~km}^{-1}$ in the $3 \mathrm{~km}$ layer. Above this layer, all values rapidly decrease; however, the extinction coefficient still exceeds $0.01 \mathrm{~km}^{-1}$ until a height of $5 \mathrm{~km}$. For the background case of $26 \mathrm{March}$, the extinction coefficient is much lower, less than $0.003 \mathrm{~km}^{-1}$, above $3 \mathrm{~km}$. Between 5 and $6 \mathrm{~km}$, the extinction coefficient on 26 March is close to that on 23 March.

The scattering and absorption coefficient profiles show a structure similar to that for sun photometer extinction; however, the extinction coefficient derived from these two scattering and absorption coefficients seems to underestimate slightly the extinction coefficient from the sun photometer (middle and bottom of Fig. 7). On 23 March, the scattering coefficients are about 0.02 and $0.03 \mathrm{~km}^{-1}$ up to $3.5 \mathrm{~km}$, and then decrease to less than 0.01 in the $4 \mathrm{~km}$ layer, and then to less than $0.002 \mathrm{~km}^{-1}$ at higher levels. On 26 March, the scattering coefficients in the lowest $2 \mathrm{~km}$ are about $0.01 \mathrm{~km}^{-1}$, and the values rapidly decrease above $2 \mathrm{~km}$; however, a slight increase occurs near $5 \mathrm{~km}$ such that the values at this height exceed those for 23 March. The absorption coefficient profiles have larger variability, partly due to the large experimental uncertainties. Nevertheless, the data show that 23 March has greater absorption than 26 March for heights up to $3 \mathrm{~km}$ (the respective values are about $0.003 \mathrm{~km}^{-1}$ and $0.001 \mathrm{~km}^{-1}$ or less, except that 26 March has a peak just above $3 \mathrm{~km}$ that is comparable to that of a slightly lower altitude on $23 \mathrm{March}$ ). From these scattering coefficients and absorption coefficients we estimated the single-scattering albedo. The single-scattering albedo ranged between 0.85 and 0.9 for the first $3 \mathrm{~km}$ on 23 March, and for the upper layer varied between 0.75 and 0.95 . These are consistent with other measurements. Clarke et al. (1984) reported a single-scattering albedo in the range of 0.77 to 0.93 with a mean value of 0.86 for a haze case in 1982 at Barrow; and Clarke (1989) reported similar values for the scattering and absorption coefficients from the measurements of AGASP II in 1986 at Barrow. On 26 March, the single-scattering albedo ranged between 0.74 and 0.92 , except for one layer which was 0.56 . From the point of vertical profile, aerosol loading in the lowest layer is common in the background case; however, Arctic haze events are characterized by larger aerosol loadings in mid-troposphere.

The shapes of the curve for 23 March in Fig. 7, obtained from the airborne measurement at about 12:00 UT, agrees with the simultaneous LIDAR measurements, which showed a stable aerosol layer up to about $2.5 \mathrm{~km}$ (see Fig. 6). This aerosol layer is present in both profiles. Moreover, for this aerosol layer, a $60 \%$ reduction in extinction coefficient between the two days was calculated. On 23 March, the absorption and scattering coefficient profiles showed a significant second layer between 2 and $3 \mathrm{~km}$, which was well represented by the LIDAR profile. Values found 

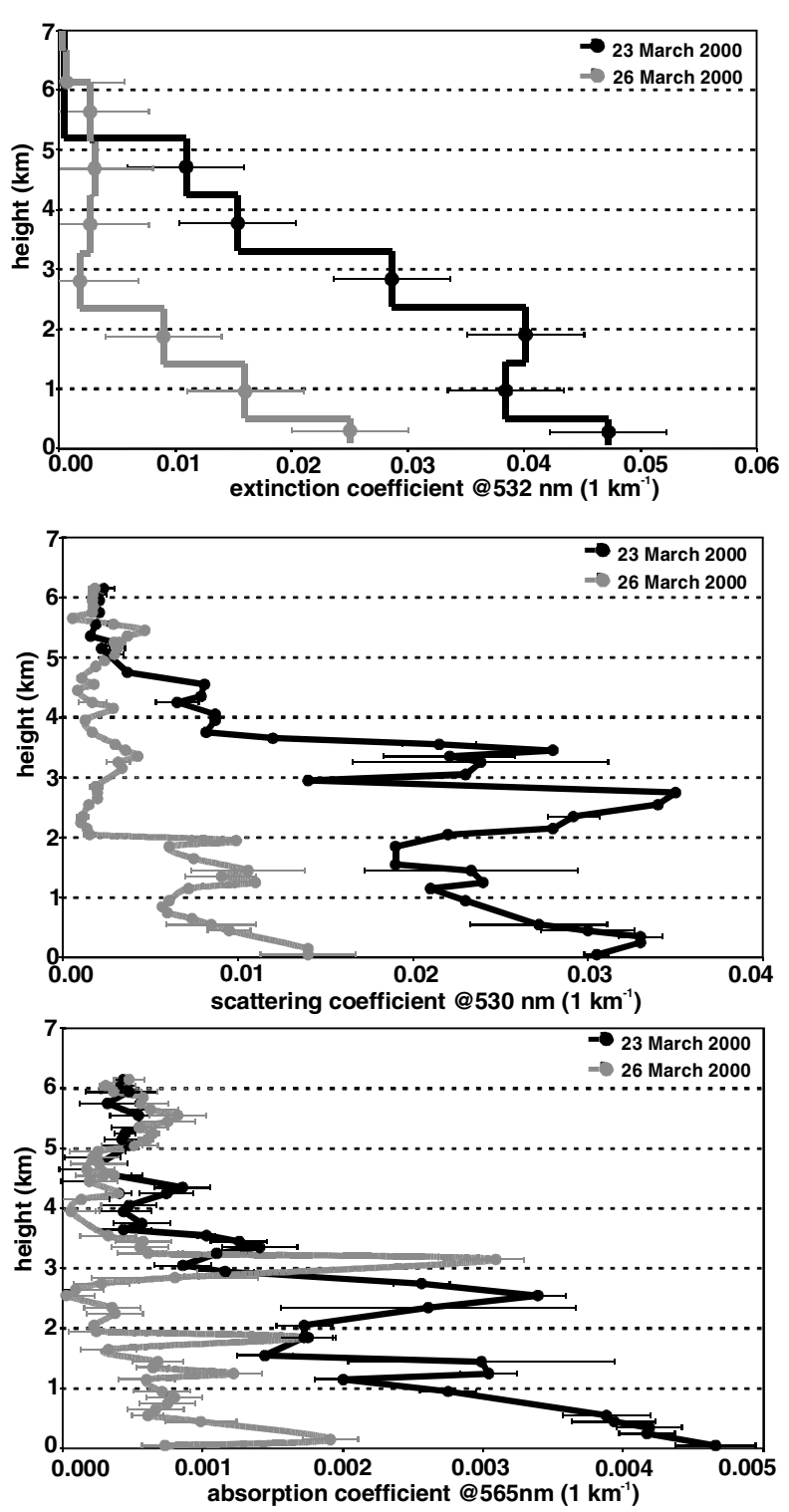

Fig 7. Vertical profiles of aerosol extinction, absorption and scattering coefficients for 23 and 26 March (Treffeisen et al., 2004). For the extinction coefficient, the value of the mean measured layer is marked and the vertical steps in the curves show the layer thickness. The continuous scattering and absorption coefficients are averaged over a height of $100 \mathrm{~m}$. The profile of the scattering coefficient is humidity-corrected based on a method by Hegg et al. (1996).

for the scattering coefficient in the first flight levels were similar to the surface results from Zeppelin and Rabben.

Other useful information on the height-dependent aerosol variation can be obtained by analysing the aircraft OPC measurements. Figure 8 shows the aerosol particle number concentration as a function of height for four size ranges. As expected, the particle number concentration profiles differ between the two days and are consistent with the optical measurements. The profiles for particles larger than $1 \mu \mathrm{m}$ (not shown here) and sizes of 0.5 to $1.0 \mu \mathrm{m}$ indicated a continuous decrease with altitude for both days. The size ranges $0.3-0.5 \mu \mathrm{m}$ and $0.2-$ $0.3 \mu \mathrm{m}$, which are relevant to the optical properties in visible radiation, were well structured and thus matched the layer structure recorded by the absorption and scattering coefficient profiles. On 23 March, the particle number concentrations in both size ranges showed a gradual decrease from the surface to $2 \mathrm{~km}$, then a high-concentration layer at $2-3 \mathrm{~km}$ and again at $3-4 \mathrm{~km}$, which is similar to the vertical profile of the scattering coefficient. For these size ranges, particle number concentrations are lower on 26 March (Fig. 8). On 26 March, there is a gradual decrease from the surface to $1 \mathrm{~km}$, a small increase at $1-2 \mathrm{~km}$, a great reduction at $2 \mathrm{~km}$, and a small increase at 5-6 km that shows a little larger value than that on 23 March. The size range of $0.1-0.2 \mu \mathrm{m}$ is an exception; the profiles were rather different from those of extinction, scattering and absorption coefficients and for the first $3 \mathrm{~km}$ the particle number concentration for 26 March was larger than that for 23 March. The profile on the 23 March was smaller in the lower level and generally increased up to $4 \mathrm{~km}$, whereas on the 26 March the profile showed a gradual decrease, but both profiles were more uniform than those in other size ranges.

One of the aims of the project was to obtain an Arctic spring aerosol data set. Thus knowledge of the height-dependent chemical composition from aircraft measurements is essential (e.g. for estimating the aerosol mass mixing ratio). The main results of the entire airborne impactor measurements have already been discussed in detail in Hara et al. (2002, 2003). The findings for 23 and 26 March are as follows: the main components were sulfate, soot and sea salt particles; smaller components include a small number of mineral dust particles. Sulfate particles were the most dominant component. This observation agrees with previous results on Arctic spring aerosols (Heintzenberg and Lack, 1994).

However, the height-dependent relative number concentration differed for both days. For the haze condition on 23 March, a relatively high proportion of externally mixed soot particles were found, and on 26 March there were a significant number of particles with an internal mixture of soot in sulfate. Sea salt was observed in both cases in the lower troposphere, and the relative abundance was similar. For 23 March we conclude that the first $3 \mathrm{~km}$ were mainly dominated by sulfate particles and the layer above had an external mixture of soot. This correlates with the measured absorption coefficient, which showed increased values near $3 \mathrm{~km}$ (Fig. 7, bottom). This also corresponds to the increased particle number concentration for smaller particles in this height range (Fig. 8, bottom). The aerosol particles associated with direct transport from anthropogenic source regions (23 March) contained a high concentration of small external mixed soot, whereas air masses with a longer residence time in the Arctic (26 March) contained significant amounts of internal soot mixtures even though the total particle 

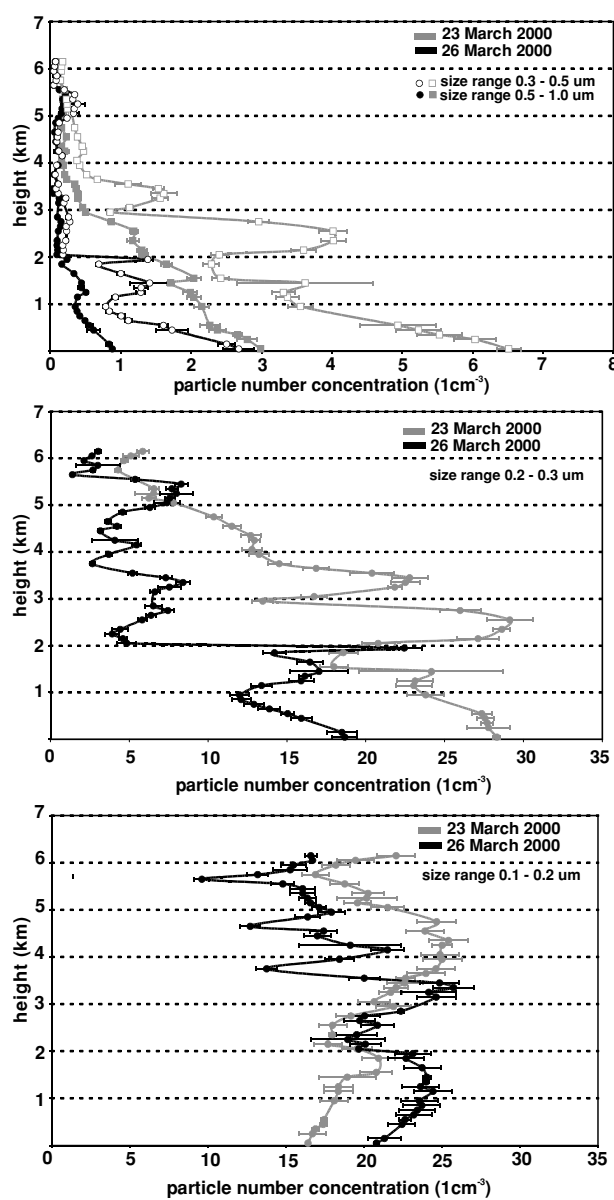

concentrations were very low compared with the haze situation on 23 March. These internal soot mixtures are of special interest due to the fact that they might have a larger influence on radiative forcing at high latitudes than external soot mixtures (Myhre et al., 1998).

\section{Summary}

This paper reports on the results for a distinct haze event during the ASTAR 2000 field campaign conducted in March and April 2000 in the Svalbard area. During ASTAR, intensive flight activities and coordinated ground-based measurements were performed. The influence of large-scale meteorological changes was reflected in both the airborne and ground-based measurements. All measurements complemented one another and gave a consistent picture of the aerosol characteristics during the haze event on 23 March. The results showed the available capacity of the campaign to gain a valuable data set for spring Arctic aerosol characteristics.

The campaign provided a wide range of various independent optical, chemical and physical aerosol parameters with a high vertical and horizontal resolution. With this data set we could describe the spatial and temporal variability of aerosols near mean layer value $\left(1 \mathrm{~cm}^{-3}\right)$

$$
23 \text { March } 26 \text { March }
$$

$5-1.0 \mu \mathrm{m}$

$0.2 \pm 0.03 \quad 0.1 \pm 0.05$

$0.3 \pm 0.1 \quad 0.08 \pm 0.04$

$1 \pm 0.3 \quad 0.1 \pm 0.02$

$2 \pm 0.4 \quad 0.5 \pm 0.2$

size range $0.3-0.5 \mu \mathrm{m}$

$>4 \mathrm{~km} \quad 0.2 \pm 0.1 \quad 0.1 \pm 0.1$

$\begin{array}{lll}-3 \mathrm{~km} & 3 \pm 1 & 0.2 \pm 0.04\end{array}$

23 March 26 March

$8 \pm 3$

$5 \pm 2$

$19 \pm 4$

$24 \pm 6$

$6 \pm 2$

$5 \pm 1$

$2 \pm 6$
Fig 8. Particle number concentrations from airborne OPC measurements for 23 and 26 March. The measurements are averaged over a height of $100 \mathrm{~m}$ and are separated into particle diameters $0.1-0.2 \mu \mathrm{m}, 0.2-0.3 \mu \mathrm{m}$, $0.3-0.5 \mu \mathrm{m}$ and $0.5-1.0 \mu \mathrm{m}$.

Svalbard in the European Arctic. One goal for the ASTAR campaign was to derive the necessary input parameters afterwards for radiative transfer calculations and modelling by combining all measured aerosol information.

\section{Acknowledgments}

The German Research Council (DFG) and BMBF/BEO Bereich Polar- und Meeresforschung supported this research. This work was also supported by the Ministry of Education, Culture, Sports, Science and Technology of Japan within the Special Scientific Research Program (no 11208201) and Grant-in Aid (no 11691138). The support provided by the local authorities and companies was very important for the smooth running of the work, especially Luftfartsverket, Lufttransport, NPI Longyerabyen and Kings Bay AS Ny-Ålesund. We thank the ASTAR 2000 team in Ny-Ålesund, including the staff of the participating stations: Koldewey Station, AWI Bremerhaven/Potsdam; Rabben station, NIPR Tokyo, Hokkaido University, Nagoya University; Zeppelin station, NILU Kjeller, MISU Stockhom; Sverdrup station (NPI Tromsoe) and SOUSY Svalbard Radar, Longyearbyen (MPI, Lindau). Special thanks go to the complete airborne team. We are grateful to Arne Tølås (DMNI Troms $\varnothing$ ) 
for his briefing, which made it possible for us to do successful flight operations. We thank Yuji Fujitani (Hokkaido University), Takashi Shibata and Chiharu Nishita (Nagoya University), Naohiko Hirasawa (NIPR), Kazue Suzuki (Graduate School for Advanced Study) and Siegrid Debatin and Juergen Graeser (AWI Potsdam) for the field observation and data analysis support.

\section{References}

Anderson, T. L., Covert, D. S., Marshall, S. F., Laukcs, M. L., Charlons, R. J. and co-authors. 1996. Performance characteristics of a highsensitivity, three-wavelength, total scatter/backscatter nephelometer. J. Atmos. Ocean. Technol. 13, 967-986.

Ansmann, A., Riebesell, M. and Weitkamp, C. 1990. Measurement of atmospheric aerosol extinction profiles with a Raman lidar. Opt. Lett. 15, 746-748.

Bodhaine, B. A. and Dutton, E. G. 1993. A long-term decrease in Arctichaze at Barrow, Alaska. Geophys. Res. Lett. 20, 947-950.

Bond, T., Anderson, T. and Campbell, D. 1999. Calibration and intercomparison of filter-based measurements of visible light absorption by aerosols. Aerosol Sci. Technol. 30, 582-600.

Chapman, W. L. and Walsh, J. E. 1993. Recent variations of sea ice and air temperature in high latitudes. Bull. Am. Meteorol. Soc. 74, 33-47.

Clarke, A. D. 1989. In-situ measurements of the aerosol size distributions, physicochemistry and light absorption properties of Arctic haze. J. Atmos. Chem. 9, 255-266.

Clarke, A. D., Charlson, R. J. and Radke, L. F. 1984. Airborne observations of Arctic aerosol, IV: Optical properties of Arctic haze. Geophys. Res. Let. 11, 405-408.

Dethloff, K., Rinke, A., Lehmann, R., Christensen, J. H., Botzet, M. and co-authors. 1996. Regional climate model of the Arctic atmosphere. J. Geophys. Res. 101, 23 401-23 422.

Eneroth, K., Kjellström, E. and Holmén, K. 2003. A trajectory climatology for Svalbard; investigating how atmospheric flow patterns influence observed tracer concentrations. Phys. Chem. Earth 28, 11911203.

Engardt, M. and Holmén, K. 1999. Model simulations of anthropogenic $\mathrm{CO}_{2}$-transport to an Arctic monitoring station during winter. Tellus 51B, 194-209.

Hara, K., Osada, K., Nishita, C., Yamagata, S., Yamanouchi, T. and co-authors. 2002. Vertical variations of sea-salt modification in the boundary layer of spring Arctic during the ASTAR 2000 campaign. Tellus 54B, 361-376.

Hara, K., Yamagata, S., Yamanouchi, T., Sato, K., Herber, A. and coauthors. 2003. Mixing states of individual aerosol particles in spring Arctic troposphere during ASTAR 2000 campaign. J. Geophys. Res. 108(D7) 4209, doi:10.1029/2002JD002513.

Hegg, D. A., Covert, D. S., Rood, M. J. and Hobbs, P. V. 1996. Measurements of aerosol optical properties in marine air. J. Geophys. Res. 101(D8), $12893-12903$.

Heintzenberg, J. 1989. Arctic haze: air pollution in the Polar regions. Ambio 18, 50-55.

Heintzenberg, J. and Lack, C. 1994. Seasonal variation of the atmospheric aerosol near the top of the marine boundary layer over Spitzbergen related to the Arctic sulphur cycle. Tellus 46B, 5267.
Herber, A., Thomason, L. W., Gernandt, H., Leiterer, U., Nagel, D. and co-authors. 2002. Continuous day and night aerosol optical depth observations in the Arctic between 1991 and 1999. J. Geophys. Res. 107(D10), doi:10.1029/2001JD000536.

Hoff, A. 2000. Final Report of Aircraft Services-ASTAR'2000, Aerodata, Braunschweig.

IPCC 2001. Climate Change: The Scientific Basis, 2001. Cambridge University Press, New York.

Iversen, T. and Joranger, E. 1985. Arctic air pollution and large-scale atmospheric flow. Atmos. Environ. 19, 2099-2108.

Jokinen, V. and Mäkelä, J. M. 1997. Closed-loop arrangements with critical orifice for DMA sheath/excess flow system. J. Aerosol Sci. 28, 643-648.

Knutson, E. O. and Whitby, K. T. 1975. Aerosol classification by electric mobility: apparatus, theory and applications. J. Aerosol Sci. 6, 443451.

Kriews, M. and Schrems, O. 1998. Aerosol sampling depending on precipitation at Spitsbergen. J. Aerosol Sci. 29, 685-686.

Luedke, C., Hoffmann, E., Skole, J. and Kriews, M. 1999. Determination of trace metals in size fractionated particles from Arctic air by electrothermal vaporization inductively coupled plasma mass spectrometry. J. Anal. At. Spectrom. 14, 1685-1690.

Myhre, G., Stordal, F., Restad, K. and Isaksen, I. 1998. Estimation of the direct radiative forcing due to sulfate and soot aerosols. Tellus 50B, 463-477.

Nagel, D., Herber, A., Thomason, L. W. and Leiterer, U. 1998. Vertical distribution of the spectral aerosol optical depth in the Arctic from 1993 to 1996. J. Geophys. Res. 103, 1857-1870.

Nakajima, T., Tonna, G., Rao, R., Boi, P., Kaufman, Y. and co-authors. 1996. Use of sky brightness measurements from ground for remote sensing of particulate polydispersions. Appl. Opt. 35, 2672-2686.

Raatz, W. E. 1991. The climatology and meteorology of Arctic air pollution. In: Pollution of the Arctic Atmosphere (ed. W. T. Sturges). Elsvier Science, New York, 13-42.

Radke, L. F., Lyons, J. H., Hegg, D. A. and Hobbs, P. V. 1984. Airborne observation of Arctic aerosol, I: Characteristic of Arctic haze. Geophys. Res. Lett. 11, 393-396.

Rothrock, D. A., Yu, Y. and Maykut, G. A. 1999. Thinning of the Arctic sea-ice cover. Geophys. Res. Lett. 26, 3469-3472.

Schnell, R. C. 1984. Arctic haze and the Arctic Gas and Aerosol Sampling Program (AGASP). Geophys. Res. Lett. 11, 361-364.

Schumacher, R., Neuber, R., Herber, A., Rairoux, P. and Schrems, O. 2000. Extinction profiles measured with a Raman Lidar in the Arctic troposphere. In: Advances in Laser Remote Sensing-Selected Papers, Presented at the 20th ILRC, Vichy, France 10-14th July 2000 (eds A. Dabas, C. Loth, and J. Pelon). Ecole Polytechnique, Palaiseau, 229232.

Shaw, G. E. 1982. Atmospheric turbidity in the Polar regions. J. Appl. Meteorol. 21, 1080-1088.

Serreze, M. C., Walsh, J. E., Chapin, F. S. III, Osterkamp, T., Dyurgerov, M. et al. 2000. Observational evidence of recent change in the northern high-latitude environment. Clim. Change 46, 159-207.

Shiobara, M. 2000. Arctic cloud and aerosol observations using a micro-pulse Lidar in Svalbard. Proc. 1st International Workshop on Space-borne Cloud Profiling Radar, Tsukuba, 24-26 January 2000, Communications Research Laboratory, Kashima, Japan, 179182. 
Spinhirne, J. D. 1993. Micro pulse Lidar. IEEE Trans. Geosci. Remote Sens. 31, 48-54.

Ström, J., Umegård, J., Tøseth, K., Turnved, P., Hansson, H.-C. and co-authors. 2003. One year observation of particle size distribution and aerosol chemical composition at the Zeppelin Station, Svalbard, March 2000-March 2001. Phys. Chem. Earth. 28, 1181-1190.

Thomason, L. W., Herber, A., Yamanouchi, T., Sato, K. and Burton, S. P. 2003. Arctic Study on Tropospheric Aerosol and Radiation: comparison of tropospheric aerosol extinction profiles measured by airborne photometer and SAGE II. Gephys. Res. Lett. 30(6), 1328, doi:10.1029/2002GL016453.

Treffeisen, R., Herber, A., Ström, J., Shiobara, M., Yamanouchi, T. and co-authors. 2004. Interpretation of Arctic aerosol properties using cluster analysis applied to observations in the Svalbard area. Tellus 56B, 457-476.

Walsh, J. E. and Chapmann, W. L. 1998. Arctic cloud-radiationtemperature associations in observational data and atmospheric reanalyses. J. Clim. 11, 3030-3045.

Wang, P. H., Kent, D. G. S., Veiga, R. E., Yue, G. K., Poole, L. R. and co-authors. 1999. A method for identifying the aerosol-only mode of SAGE II 1.02- $\mu$ m extinction coefficient data at altitudes below 6.5 km. J. Geophys. Res. 104, 9609-9615.

Weller, M., Schulz, E., Leiterer, U., Naebert, T., Herber, A. and coauthors. 1998. Ten years of aerosol optical depth observation at the Lindenberg Meteorological Observatory. Contrib. Atmos. Phys. 71, 387-400. 